\title{
Feasibility of a Proactive Text Messaging Intervention for Smokers in Community Health Centers: Pilot Study
}

Gina Kruse ${ }^{1,2,3}$, MPH, MD; Jennifer HK Kelley ${ }^{2}$, RN, MSN; Karen Chase ${ }^{4}$, BA; Nancy A Rigotti ${ }^{1,2,3}$, MD

\author{
${ }^{1}$ Division of General Internal Medicine, Massachusetts General Hospital, Boston, MA, United States \\ ${ }^{2}$ Tobacco Research and Treatment Center, Massachusetts General Hospital, Boston, MA, United States \\ ${ }^{3}$ Harvard Medical School, Boston, MA, United States \\ ${ }^{4}$ Partners Center for Connected Health, Partners HealthCare, Somerville, MA, United States
}

\section{Corresponding Author:}

Gina Kruse, MPH, MD

Division of General Internal Medicine

Massachusetts General Hospital

100 Cambridge Street, 16th Floor

Boston, MA, 02114

United States

Phone: 16177243157

Email: gkruse@ partners.org

\section{Abstract}

Background: Few smokers receive evidence-based cessation services during primary care visits.

Objective: We aimed to assess the feasibility of a proactive text messaging program for primary care patients who smoke.

Methods: We used electronic health records to identify smokers who had a mobile phone number listed from two community health centers in Massachusetts. Between March 2014 and June 2015, patients were screened by their primary care physician and then sent a proactive text message inviting them to enroll by texting back. Patients who opted in were asked about their readiness to quit. The text message program included messages from the QuitNowTXT library and novel content for smokers who were not ready to quit.

Results: Among 949 eligible smokers, 88 (9.3\%) enrolled after receiving a single proactive text message. Compared with those who did not enroll, enrollees were more often female $(54 / 88,61 \%$ vs $413 / 861,48.0 \%, P=.02)$, but otherwise did not differ in age, race, insurance status, or comorbidities. In all, 28\% (19/67) of enrollees reported they were not ready to quit in the next 30 days, $61 \%(41 / 67)$ were ready to quit, and $11 \%$ (7/67) already quit. The median time in the program was 9 days (interquartile range 2-32 days). Of current smokers, 25\% (15/60) sent one or more keyword requests to the server. These did not differ by readiness to quit.

Conclusions: A proactively delivered text messaging program targeting primary care patients who smoke was feasible and engaged both smokers ready to quit and those not ready to quit. This method shows promise as part of a population health model for addressing tobacco use outside of the primary care office.

(JMIR Formativ Res 2018;2(1):e11) doi: 10.2196/formative.9608

\section{KEYWORDS}

smoking cessation; primary health care; text messaging

\section{Introduction}

Among US smokers, less than one-third use any assistance-pharmacologic or behavioral—when they try to quit smoking [1]. Text messaging shows promise as a way to assist smokers to quit by delivering behavioral advice. Prior studies indicate that text messaging interventions for smokers increase tobacco abstinence rates by $36 \%$ to $70 \%$ [2-13].
However, most prior text messaging studies recruited motivated smokers through public advertisements, the Internet, or school-based recruitment. The few text messaging studies that recruited smokers from health care settings targeted motivated smokers [14], those already in tobacco treatment programs [15], pregnant smokers [16], or patients with coronary disease [17]. The feasibility of delivering tobacco cessation assistance by 
text message for the broader population of smokers in primary care is unknown.

Primary care practices are well positioned to promote smoking cessation because $70 \%$ of smokers visit a physician each year [18]. However, although physicians often recommend quitting during visits, competing priorities and time constraints prevent them from offering further assistance [19]. Thus, new proactive models of care delivery are being developed for smokers [20-26]. These programs reach out to patients who are listed as smokers in electronic health records (EHRs) between visits to offer them help [27]. Prior models using mailings and telephone calls to engage smokers produced increases in treatment use and tobacco abstinence [20-26]. Text messaging interventions may be a less costly way to increase the reach and engagement of smokers in these proactive models [28].

Proactive models allow health systems to reach out to all smokers, not just those seeking treatment. In the United States, $80 \%$ of smokers are not ready to quit in the next 30 days [29]. However, smokers who are not ready to quit report substantial interest in mobile health interventions [30]. A low-intensity intervention such as text messaging may be a better fit with the treatment preferences of smokers who are not ready to quit compared to more intensive or intrusive treatments. Furthermore, even moderately efficacious interventions that target the large proportion of smokers who are not ready to quit may have a large public health impact [31]. The objective of this study was to assess the feasibility of delivering a proactive text messaging intervention for smokers in primary care in terms of proportion of patients reached, their interaction, and duration of time spent with the program.

\section{Methods}

\section{Participants}

We recruited smokers receiving primary care at Massachusetts General Hospital-affiliated community health centers in Charlestown and Revere, Massachusetts. We identified patients receiving primary care using a validated algorithm used by the Massachusetts General Hospital Practice-Based Research Network [32]. Other eligibility criteria based on EHR data included a primary language of English, age 18 years and older, current smoker, and with a mobile telephone number.

\section{Intervention}

We developed the GetReady2Quit (R2Q) text messaging program with content for smokers ready to quit in the next 30 days and content for smokers not ready to quit (Table 1). For smokers who were ready to quit in the next 30 days, we used the downloadable QuitNowTXT library [33]. QuitNowTXT includes 118 messages delivered over 6 weeks tailored to a user-entered quit date. These messages include behavioral advice and motivational and educational messages about the harms of tobacco and the benefits of quitting. The program has limited two-way communication including keywords to request help by texting "CRAVE," "MOOD," or "SLIP." There were also weekly smoking status assessment messages that invited a user response. Unlike other text messaging programs [34], if a user did not respond to an assessment, no further messages were sent. Maximum message volume was 25 messages per week with the highest volume in the 2 weeks before and after the quit date. For smokers who were not ready to quit in the next 30 days, 31 novel messages were developed by an expert team of primary care physicians (PCPs), a tobacco cessation counselor, a mobile health manager, and a behavioral scientist.

Table 1. Sample messages from GetReady2Quit (R2Q).

\begin{tabular}{|c|c|c|}
\hline Type & Example & Reference \\
\hline Opt in & Reply "yes" to participate in the R2Q Text Connect program offered to you by your doctor. & - \\
\hline \multicolumn{3}{|c|}{ Campaign for smokers ready to quit in the next 30 days } \\
\hline Behavioral advice & $\begin{array}{l}\text { Next time you have the urge to smoke, try and resist for } 5 \text { minutes. Or skip the cigarette entirely. } \\
\text { Think of it as practice for quit day! }\end{array}$ & {$[33]$} \\
\hline Motivational messages & $\begin{array}{l}\text { Need motivation? Make a list of your reasons for quitting. Put it someplace you can see every } \\
\text { day. Keep thinking about why you want to quit. }\end{array}$ & {$[33]$} \\
\hline Educational messages & $\begin{array}{l}\text { Lung capacity increases by } 30 \% \text { after a few weeks without cigarettes! Ride your bike or take a } \\
\text { walk. Put your healthy lungs to good use! }\end{array}$ & {$[33]$} \\
\hline Smoking status & Are you still smokefree? Reply: YES or NO. & {$[33]$} \\
\hline Keywords & $\begin{array}{l}\text { Text your supporters and remind them of the big day. Make sure they are there for you. Text } \\
\text { back CRAVE, MOOD, or SLIP for more support anytime. }\end{array}$ & {$[33]$} \\
\hline \multicolumn{3}{|c|}{ Campaign for smokers not ready to quit in the next 30 days } \\
\hline Motivational messages & $\begin{array}{l}\text { Write down your reasons to quit. Put your reasons someplace where you will see them when you } \\
\text { smoke, like in your car, your kitchen, or at your computer. }\end{array}$ & {$[35]$} \\
\hline Practice quit attempt & $\begin{array}{l}\text { A practice quit attempt is a few hours or days when you don't smoke to learn how you will feel } \\
\text { when quit for real. Try it this week! }\end{array}$ & {$[36]$} \\
\hline Readiness to quit & $\begin{array}{l}\text { Are you ready to quit for good? If yes, reply with the date you would like to quit on, in this format: } \\
\text { MMDD, for ex: } 0513 \text { for May } 13 \text {. If not, reply WAIT. }\end{array}$ & - \\
\hline
\end{tabular}


Content included 16 motivational messages to encourage individuals to identify personal reasons for change and internal motivations to quit $[35,37]$. Fifteen messages encouraged smokers to try a practice quit attempt explained as an attempt to not smoke for hours or days without a commitment to stop for good [36]. Practice quit attempts can increase motivation and self-efficacy [36,38]. Smokers not ready to quit were sent three to five messages per week. At the end of this message campaign, users were asked again if they were ready to quit in the next 30 days. Those that were ready were sent the QuitNowTXT messages. Those that were not ready were sent a final recommendation to contact their doctor or the state quitline.

\section{Procedures}

Between March 2014 and June 2015, PCPs were asked to screen potentially eligible patients. The PCP-approved patients were sent an opt-out letter (Multimedia Appendix 1), informing them about the purpose of the feasibility study, content of the R2Q text messaging program, and that they would be sent a text message in the next week unless they called to opt out. Patients who did not opt out were sent a single text message inviting them to opt in to the R2Q program (Table 1). Opting in implied consent. Participants were sent four text message queries assessing nicotine dependence, readiness to quit, and quit date. Ethical approval was obtained from the Partners Healthcare, Inc Institutional Review Board.

\section{Statistical Analysis}

We compared R2Q enrollees, those who opted in following the proactive text message, with patients who were eligible and invited but who did not enroll in terms of demographics, primary insurance, and comorbidities. We used portions of the Reach
Effectiveness Adoption Implementation Maintenance (RE-AIM) methodology [31] to measure program reach, engagement, and adoption. Reach was the proportion of users sent a proactive text invitation who opted in. Engagement was measured as sending one or more keywords to the server. Adoption was defined as days in the text messaging program before the participant texted "STOP" or failed to respond to an assessment message. We compared engagement and adoption by readiness to quit using unadjusted $t$ tests, Wilcoxon rank sum tests, and chi-square tests.

\section{Results}

We identified 1279 adults who met our inclusion criteria. Of these, 949 patients were reviewed and approved by their PCP for recruitment and 88 patients enrolled by opting in to the program after a single recruitment text for a reach of $9.3 \%$ (Figure 1).

Enrollees were more likely to be female and were less likely to have cardiovascular disease, but did not otherwise differ from eligible patients who were sent the opt-in text but who did not enroll (Table 2). Of the 88 enrollees, 67 (76\%) completed all query messages about readiness to quit and nicotine dependence. Seven enrollees $(11 \%)$ had already quit, 19 (28\%) were not ready to quit, and $41(61 \%)$ were ready to quit in the next 30 days. Of the 60 current smokers, median time in the program was 9 days (interquartile range [IQR] 2-32 days). Fifteen of 60 $(25 \%)$ current smokers engaged with the program by texting keyword messages (eg, CRAVE, MOOD, or SLIP). Program time and engagement did not differ by readiness to quit (Table 3 ). However, compared to smokers not ready to quit, those ready to quit received more messages (median 18, IQR 14-40 vs median 12, IQR 7-44, P=.04).

Figure 1. GetReady2Quit patient enrollment flow. Eligible patients were adults ( $>18$ years) listed as current smoker in their electronic health record (EHR) with English listed as primary language. PCP: primary care physician.

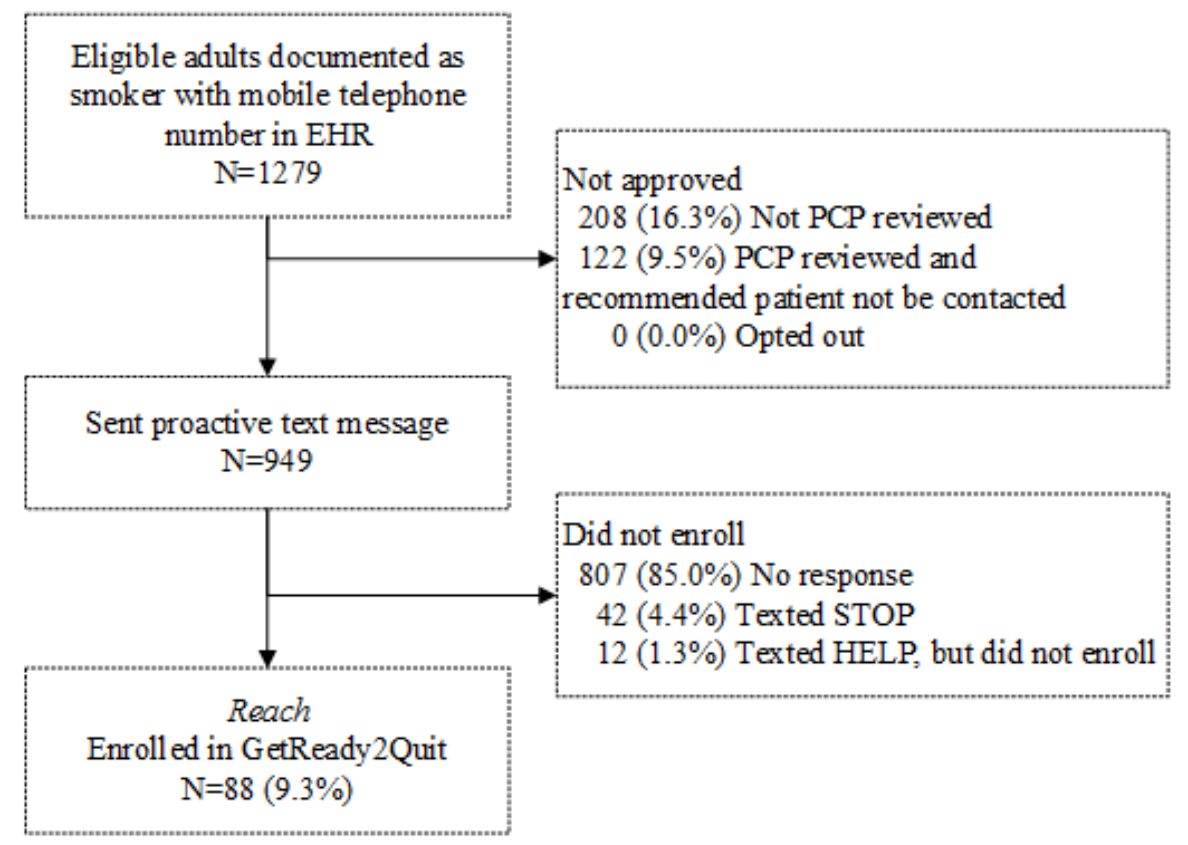


Table 2. Characteristics of eligible participants by GetReady2Quit enrollment status.

\begin{tabular}{|c|c|c|c|c|c|}
\hline Characteristics & Enrolled (N=88) & Did not enroll $(\mathrm{N}=861)$ & $\chi^{2}(\mathrm{df})$ & $t_{944}$ & $P$ \\
\hline \multicolumn{6}{|l|}{ Demographics } \\
\hline Gender (female), n (\%) & $54(61.4)$ & $413(48.0)$ & $5.7(1)$ & - & .02 \\
\hline Race (white), n (\%) & $78(89.7)$ & $754(87.8)$ & $0.3(1)$ & - & .61 \\
\hline Age (years), mean (SD) & $47(12)$ & $48(14)$ & - & 0.7 & .50 \\
\hline Primary insurance, $n(\%)$ & - & - & $1.8(3)$ & - & .61 \\
\hline Commercial insurance & $52(59.8)$ & $458(53.3)$ & - & - & - \\
\hline Medicaid & $18(20.7)$ & $233(27.1)$ & - & - & - \\
\hline Medicare & $15(17.2)$ & $149(17.4)$ & - & - & - \\
\hline Self-pay & $2(2.3)$ & $19(2.2)$ & - & - & - \\
\hline \multicolumn{6}{|l|}{ Comorbidities, n (\%) } \\
\hline Cardiovascular disease & $3(3.4)$ & $87(10.1)$ & $4.2(1)$ & - & .04 \\
\hline Diabetes mellitus & $11(12.5)$ & $88(10.2)$ & $0.4(1)$ & - & .51 \\
\hline Hypertension & $22(25.0)$ & $255(29.6)$ & $0.8(1)$ & - & .36 \\
\hline Chronic kidney disease & $1(1.1)$ & $13(1.5)$ & $0.1(1)$ & - & .78 \\
\hline Depression & $2(2.3)$ & $25(2.9)$ & $0.1(1)$ & - & .74 \\
\hline
\end{tabular}

Table 3. Characteristics of enrolled smokers by readiness to quit.

\begin{tabular}{|c|c|c|c|c|c|c|}
\hline Characteristics & Ready to quit $(\mathrm{n}=41)$ & Not ready to quit $(\mathrm{n}=19)$ & $\chi_{1}^{2}$ & $t_{48}$ & $z$ & $P$ \\
\hline Cigarettes per day, mean (SD) & $15(7)$ & $15(5)$ & - & -0.1 & - & .92 \\
\hline Time to first cigarette ( $<30$ minutes), $\mathrm{n}(\%)$ & $32(80)$ & $10(77)$ & 0.1 & - & - & .81 \\
\hline Messages received, median $\left(\mathrm{IQR}^{\mathrm{a}}\right)$ & $18(14-40)$ & $12(7-44)$ & - & - & -2.0 & .04 \\
\hline Engagement (program days), median (IQR) & $16(3-31)$ & $4(1-35)$ & - & - & -0.8 & .40 \\
\hline Adoption (texted a keyword), n (\%) & $13(32)$ & $2(11)$ & 3.1 & - & - & .08 \\
\hline
\end{tabular}

${ }^{\mathrm{a}} \mathrm{IQR}$ : interquartile range.

\section{Discussion}

\section{Comparison With Prior Work}

This study evaluated a proactive tobacco cessation intervention that reached out to patients by text message. It shows promise as a low-cost, scalable intervention for primary care populations. Program reach at $9.3 \%$ was comparable to other proactive care models for smokers that used more intensive outreach methods, including up to 15 outreach telephone calls [24]. Similar to telephone outreach programs, both smokers ready to quit and those not ready to quit enrolled [27]. These results support the feasibility of future work to design and test a proactive text messaging intervention targeting primary care patients.

Text messaging programs originating from the physicians' office may leverage the influence physicians have on smokers [18]. Individuals most often look to their own health care systems for online health information [39]; therefore, trust in their health care providers may make health-promoting advice more potent if it is coming from their physicians' office. This trust may also encourage even unmotivated smokers to engage in health-promoting activities sent to them by their physicians' office.

Our single message enrollment process was simpler than recruitment used by other proactive care models [20-26]. The low intensity may have been appealing to both smokers not ready to quit and those busy managing other chronic diseases, who may not have time or interest in more complex interventions. Indeed, except for cardiovascular disease, patients with comorbid chronic diseases were no less likely to opt in. Integrating the program with other optional cessation services, such as pharmacotherapy, may increase the program's appeal and improve reach and effectiveness. Future work will need to explore ways for text messaging to be integrated with other cessation services available to primary care patients who smoke.

\section{Limitations}

In this pilot study, we did not have enough resources to assess smoking outcomes or receipt of text messages. Therefore, we could not account for invalid telephone numbers or failed message delivery. If these are considered, the uptake of the program following receipt of the proactive text may have been even higher. 


\section{Conclusions}

A proactively delivered text messaging program targeting primary care patients who smoke reached as many smokers with a single text as more intense and costly telephone call- or mailed-based proactive outreach methods. This method engaged both smokers ready to quit and those not ready to quit and shows promise as part of a proactive care model for addressing smoking in primary care populations.

\section{Acknowledgments}

The authors would like to acknowledge Susan Lane for her input and support and Odeta Dyrmishi for her administrative work on this project. This project was funded by Partners Health Care System, Inc. GK was supported by the National Cancer Institute grant \#5 R25 CA 0571120 for a postdoctoral fellowship, Harvard School of Public Health, Dept of Social and Behavioral Sciences and the National Institute on Drug Abuse grant \#K23 DA 038717. These sponsors had no involvement in the review or approval of the manuscript for publication.

\section{Conflicts of Interest}

GK has interests in two mobile health companies, including a family financial interest in Dimagi, Inc, and is a paid consultant for Click Therapeutics. NAR has a research grant from and served as an unpaid consultant on tobacco cessation treatment to Pfizer and receives royalties from tobacco topics in UpToDate.

\section{Multimedia Appendix 1}

Opt-out patient letter.

[PDF File (Adobe PDF File), 394KB-Multimedia Appendix 1]

\section{References}

1. Centers for Disease Control and Prevention. Quitting smoking among adults--United States, 2001-2010. MMWR Morb Mortal Wkly Rep 2011 Nov 11;60(44):1513-1519 [FREE Full text] [Medline: 22071589]

2. Whittaker R, McRobbie H, Bullen C, Rodgers A, Gu Y. Mobile phone-based interventions for smoking cessation. Cochrane Database Syst Rev 2016;4:CD006611. [doi: 10.1002/14651858.CD006611.pub4] [Medline: 27060875]

3. Head KJ, Noar SM, Iannarino NT, Grant HN. Efficacy of text messaging-based interventions for health promotion: a meta-analysis. Soc Sci Med 2013 Nov;97:41-48. [doi: 10.1016/j.socscimed.2013.08.003] [Medline: 24161087]

4. Spohr SA, Nandy R, Gandhiraj D, Vemulapalli A, Anne S, Walters ST. Efficacy of SMS text message interventions for smoking cessation: a meta-analysis. J Subst Abuse Treat 2015 Sep;56:1-10. [doi: 10.1016/j.jsat.2015.01.011] [Medline: 25720333]

5. Free C, Knight R, Robertson S, Whittaker R, Edwards P, Zhou W, et al. Smoking cessation support delivered via mobile phone text messaging (txt2stop): a single-blind, randomised trial. Lancet 2011 Jul 2;378(9785):49-55 [FREE Full text] [doi: 10.1016/S0140-6736(11)60701-0] [Medline: 21722952]

6. Chen Y, Madan J, Welton N, Yahaya I, Aveyard P, Bauld L, et al. Effectiveness and cost-effectiveness of computer and other electronic aids for smoking cessation: a systematic review and network meta-analysis. Health Technol Assess 2012;16(38):1-205, iii [FREE Full text] [doi: 10.3310/hta16380] [Medline: 23046909]

7. Abroms LC, Ahuja M, Kodl Y, Thaweethai L, Sims J, Winickoff JP, et al. Text2Quit: results from a pilot test of a personalized, interactive mobile health smoking cessation program. J Health Commun 2012;17 Suppl 1:44-53 [FREE Full text] [doi: 10.1080/10810730.2011.649159] [Medline: 22548598]

8. Brendryen H, Kraft P. Happy ending: a randomized controlled trial of a digital multi-media smoking cessation intervention. Addiction 2008 Mar;103(3):478-484; discussion 485. [doi: 10.1111/j.1360-0443.2007.02119.x] [Medline: 18269367]

9. Obermayer JL, Riley WT, Asif O, Jean-Mary J. College smoking-cessation using cell phone text messaging. J Am Coll Health 2004;53(2):71-78 [FREE Full text] [doi: 10.3200/JACH.53.2.71-78] [Medline: 15495883]

10. Riley W, Obermayer J, Jean-Mary J. Internet and mobile phone text messaging intervention for college smokers. J Am Coll Health 2008;57(2):245-248. [doi: 10.3200/JACH.57.2.245-248] [Medline: 18809542]

11. Abroms LC, Boal AL, Simmens SJ, Mendel JA, Windsor RA. A randomized trial of Text2Quit: a text messaging program for smoking cessation. Am J Prev Med 2014 Sep;47(3):242-250. [doi: 10.1016/j.amepre.2014.04.010] [Medline: 24913220]

12. Bock B, Heron K, Jennings E, Morrow K, Cobb V, Magee J, et al. A text message delivered smoking cessation intervention: the initial trial of TXT-2-Quit: randomized controlled trial. JMIR Mhealth Uhealth 2013;1(2):e17 [FREE Full text] [doi: 10.2196/mhealth.2522] [Medline: 25098502]

13. Scott-Sheldon LA, Lantini R, Jennings EG, Thind H, Rosen RK, Salmoirago-Blotcher E, et al. Text messaging-based interventions for smoking cessation: a systematic review and meta-analysis. JMIR Mhealth Uhealth 2016;4(2):e49 [FREE Full text] [doi: 10.2196/mhealth.5436] [Medline: 27207211] 
14. Cobos-Campos R, Apiñaniz Fernandez de Larrinoa A, Sáez de Lafuente Morinigo A, Parraza DN, Aizpuru BF. Effectiveness of text messaging as an adjuvant to health advice in smoking cessation programs in primary care. A randomized clinical trial. Nicotine Tob Res 2017 Aug 01;19(8):901-907. [doi: 10.1093/ntr/ntw300] [Medline: 27838659]

15. Naughton F, Jamison J, Boase S, Sloan M, Gilbert H, Prevost AT, et al. Randomized controlled trial to assess the short-term effectiveness of tailored web- and text-based facilitation of smoking cessation in primary care (iQuit in practice). Addiction 2014 Jul;109(7):1184-1193 [FREE Full text] [doi: 10.1111/add.12556] [Medline: 24661312]

16. Naughton F, Prevost AT, Gilbert H, Sutton S. Randomized controlled trial evaluation of a tailored leaflet and SMS text message self-help intervention for pregnant smokers (MiQuit). Nicotine Tob Res 2012 May;14(5):569-577. [doi: 10.1093/ntr/ntr254] [Medline: 22311960]

17. Chow CK, Redfern J, Hillis GS, Thakkar J, Santo K, Hackett ML, et al. Effect of lifestyle-focused text messaging on risk factor modification in patients with coronary heart disease: a randomized clinical trial. JAMA 2015;314(12):1255-1263. [doi: 10.1001/jama.2015.10945] [Medline: 26393848]

18. Fiore M, Jaen C, Baker T, Bailey W, Benowitz N, Curry S, et al. Treating Tobacco Use and Dependence Update. Clinical Practice Guideline. Rockville, MD: US Department of Health and Human Services; 2008. URL: https://www.ncbi.nlm.nih.gov/ books/NBK63952/ [accessed 2018-05-09] [WebCite Cache ID 6zI8MztaF]

19. Thorndike AN, Regan S, Rigotti NA. The treatment of smoking by US physicians during ambulatory visits: 19942003. Am J Public Health 2007 Oct;97(10):1878-1883. [doi: 10.2105/AJPH.2006.092577] [Medline: 17761570]

20. Ellerbeck EF, Mahnken JD, Cupertino AP, Cox LS, Greiner KA, Mussulman LM, et al. Effect of varying levels of disease management on smoking cessation: a randomized trial. Ann Intern Med 2009 Apr 07;150(7):437-446 [FREE Full text] [Medline: 19349629]

21. Murray RL, Coleman T, Antoniak M, Stocks J, Fergus A, Britton J, et al. The effect of proactively identifying smokers and offering smoking cessation support in primary care populations: a cluster-randomized trial. Addiction 2008 Jun;103(6):998-1006; discussion 1007. [doi: 10.1111/j.1360-0443.2008.02206.x] [Medline: 18422823]

22. Tzelepis F, Paul CL, Wiggers J, Walsh RA, Knight J, Duncan SL, et al. A randomised controlled trial of proactive telephone counselling on cold-called smokers' cessation rates. Tob Control 2011 Jan;20(1):40-46 [FREE Full text] [doi: 10.1136/tc.2010.035956] [Medline: 21030529]

23. Haas JS, Linder JA, Park ER, Gonzalez I, Rigotti NA, Klinger EV, et al. Proactive tobacco cessation outreach to smokers of low socioeconomic status: a randomized clinical trial. JAMA Intern Med 2015 Feb;175(2):218-226 [FREE Full text] [doi: 10.1001/jamainternmed.2014.6674] [Medline: 25506771]

24. Rigotti NA, Bitton A, Kelley JK, Hoeppner BB, Levy DE, Mort E. Offering population-based tobacco treatment in a healthcare setting: a randomized controlled trial. Am J Prev Med 2011 Nov;41(5):498-503 [FREE Full text] [doi: 10.1016/j.amepre.2011.07.022] [Medline: 22011421]

25. Fu SS, van Ryn M, Burgess DJ, Nelson D, Clothier B, Thomas JL, et al. Proactive tobacco treatment for low income smokers: study protocol of a randomized controlled trial. BMC Public Health 2014 Apr 09;14:337 [FREE Full text] [doi: 10.1186/1471-2458-14-337] [Medline: 24716466]

26. Rogers ES, Fu SS, Krebs P, Noorbaloochi S, Nugent SM, Rao R, et al. Proactive outreach for smokers using VHA mental health clinics: protocol for a patient-randomized clinical trial. BMC Public Health 2014 Dec 17;14:1294 [FREE Full text] [doi: 10.1186/1471-2458-14-1294] [Medline: 25518878]

27. Kruse GR, Chang Y, Kelley JH, Linder JA, Einbinder JS, Rigotti NA. Healthcare system effects of pay-for-performance for smoking status documentation. Am J Manag Care 2013 Jul;19(7):554-561 [FREE Full text] [Medline: 23919419]

28. Guerriero C, Cairns J, Roberts I, Rodgers A, Whittaker R, Free C. The cost-effectiveness of smoking cessation support delivered by mobile phone text messaging: Txt2stop. Eur J Health Econ 2013 Oct;14(5):789-797 [FREE Full text] [doi: 10.1007/s10198-012-0424-5] [Medline: 22961230]

29. Prochaska JO, DiClemente CC. Stages and processes of self-change of smoking: toward an integrative model of change. J Consult Clin Psychol 1983 Jun;51(3):390-395. [Medline: 6863699]

30. Borrelli B, Bartlett YK, Tooley E, Armitage CJ, Wearden A. Prevalence and frequency of mHealth and eHealth use among US and UK smokers and differences by motivation to quit. J Med Internet Res 2015 Jul 04;17(7):e164 [FREE Full text] [doi: 10.2196/jmir.4420] [Medline: 26149323]

31. Glasgow RE, Vogt TM, Boles SM. Evaluating the public health impact of health promotion interventions: the RE-AIM framework. Am J Public Health 1999 Sep;89(9):1322-1327. [Medline: 10474547]

32. Atlas SJ, Chang Y, Lasko TA, Chueh HC, Grant RW, Barry MJ. Is this ?my? patient? Development and validation of a predictive model to link patients to primary care providers. J Gen Intern Med Sep 2006;21(9):973-978. [doi: 10.1111/j.1525-1497.2006.00509.x] [Medline: 16918744 ]

33. National Cancer Institute. 2017. QuitNowTXT message library URL: https://smokefree.gov/help-others-quit/ health-professionals/resources-health-professionals [accessed 2017-12-08] [WebCite Cache ID 6vYmjpGI4]

34. Augustson E, Cole-Lewis H, Sanders A, Schwarz M, Geng Y, Coa K, et al. Analysing user-reported data for enhancement of SmokefreeTXT: a national text message smoking cessation intervention. Tob Control 2017 Nov;26(6):683-689. [doi: 10.1136/tobaccocontrol-2016-052945] [Medline: 27852892] 
35. Emmons KM, Rollnick S. Motivational interviewing in health care settings. Opportunities and limitations. Am J Prev Med 2001 Jan;20(1):68-74. [Medline: 11137778 ]

36. Carpenter MJ, Hughes JR, Gray KM, Wahlquist AE, Saladin ME, Alberg AJ. Nicotine therapy sampling to induce quit attempts among smokers unmotivated to quit: a randomized clinical trial. Arch Intern Med 2011 Nov 28;171(21):1901-1907 [FREE Full text] [doi: 10.1001/archinternmed.2011.492] [Medline: 22123796]

37. Miller WR, Rollnick S. Ten things that motivational interviewing is not. Behav Cogn Psychother 2009 Mar;37(2):129-140. [doi: 10.1017/S1352465809005128] [Medline: 19364414]

38. Jardin BF, Carpenter MJ. Predictors of quit attempts and abstinence among smokers not currently interested in quitting. Nicotine Tob Res 2012 Oct;14(10):1197-1204 [FREE Full text] [doi: 10.1093/ntr/nts015] [Medline: 22387995]

39. Viswanath K, McCloud R, Minsky S, Puleo E, Kontos E, Bigman-Galimore C, et al. Internet use, browsing, and the urban poor: implications for cancer control. J Natl Cancer Inst Monogr 2013 Dec;2013(47):199-205 [FREE Full text] [doi: 10.1093/jncimonographs/lgt029] [Medline: 24395992]

\title{
Abbreviations \\ EHR: electronic health record \\ IQR: interquartile range \\ PCP: primary care physicians \\ R2Q: GetReady2Quit
}

\author{
Edited by G Eysenbach; submitted 08.12.17; peer-reviewed by K Heron, A Kassavou; comments to author 17.03.18; revised version \\ received 29.03.18; accepted 17.04.18; published 31.05 .18 \\ Please cite as: \\ Kruse G, Kelley JHK, Chase K, Rigotti NA \\ Feasibility of a Proactive Text Messaging Intervention for Smokers in Community Health Centers: Pilot Study \\ JMIR Formativ Res 2018;2(1):e11 \\ URL: http://formative.jmir.org/2018/1/e11/ \\ doi: $10.2196 /$ formative. 9608 \\ PMID:
}

(C) Gina Kruse, Jennifer HK Kelley, Karen Chase, Nancy A Rigotti. Originally published in JMIR Formative Research (http://formative.jmir.org), 31.05.2018. This is an open-access article distributed under the terms of the Creative Commons Attribution License (https://creativecommons.org/licenses/by/4.0/), which permits unrestricted use, distribution, and reproduction in any medium, provided the original work, first published in JMIR Formative Research, is properly cited. The complete bibliographic information, a link to the original publication on http://formative.jmir.org, as well as this copyright and license information must be included. 